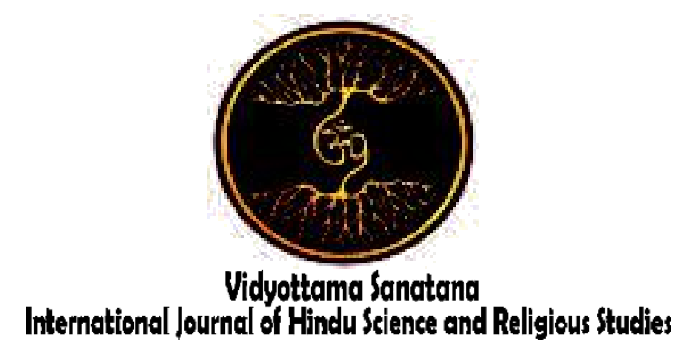

Vol. 3 No. 1 May 2019

\title{
SAD DHARMA AS A LEARNING METHOD OF HINDU RELIGIOUS EDUCATION AND CHARACTER OF 2013 CURRICULUM IN SMP GURUKULA BANGLI
}

\author{
By: \\ Ni Komang Sutriyanti, Marsono, I Nyoman Alit Supandi \\ Institut Hindu Dharma Negeri Denpasar \\ E-mail : sutriyanti@ihdn.ac.id
}

\begin{tabular}{|l|l|l|}
\hline Received: January 22, 2019 & Accepted: May 29, 2019 & Published: May 31, 2019 \\
\hline
\end{tabular}

\begin{abstract}
The success of an education is largely determined by many factors, some of the factors in supportingthese successes are the quality of human resources (HR), facilities, infrastructure, and the curriculum used. The change in curriculum requires teachers to understand and be able to implement all these changes in the learning process in the classroom, but not many teachers understand and are able to implement these changes in learning activities, especially in the use of learning methods. Therefore, this paper will attempt to examine the Sad Dharma method of learning of Hindu religious education and character entitled "Sad Dharma as a Learning Method of Hindu Religious Education and Character of 2013 Curriculum in SMPGurukula Bangli". This paper used qualitative research methods, the location of research was in SMP Gurukula Bangli, the type of data was descriptive data with primary and secondary data sources, informant determination techniques used purposive sampling technique, data collection methods used observation, interview, library study, and documentation techniques, and used data analysis techniques and presentation techniques of data analysis results. Based on the tests which were carried out, it could be stated that the Sad Dharma method was applied in its entirety starting from the dharma wacana, dharma tula, dharma santi, dharma gita, dharma sadhana, and dharma yatra. Constraints faced by its implementation were teacher, facilities, and curriculum. The implications of the implementationof Sad Dharma learning methods were the implications for spiritual attitudes, implications for social attitudes, implications for cognitive/knowledge and implications for psychomotor aspects.
\end{abstract}

Keywords: Sad Dharma Method, Learning, Hindu Religious Education and Character. 


\section{Introduction}

The Law of the Republic of Indonesia Number 20 of 2003 concerning the National Education System, in Chapter II, it formulates the basic, functions, and objectives of national education in an effort to develop education in Indonesia for the better. Referring to Article 3 of the Law of National Education System, it states that National Education functions to develop capabilities and form a dignified character and national civilization in order to educate the life of the nation. In addition, National Education aims to develop the potential of students to become human beings who believe and fear to God Almighty, have a noble character, are healthy, knowledgeable, capable, creative, independent, and become democratic and responsible citizens.

The success of an education is largely determined by many factors, several factors that can support these successes such as the quality of human resources (HR), supporting facilities and infrastructure, and the accuracy of the curriculum used. Education must be able to adjust the dynamics that develop in the community, especially the demands and needs of the community and this can be answered with curriculum changes. A teacher who will later implement the curriculum in the classroom through the learning process is deemed necessary to know and understand the curriculum that is being applied so that the objectives of the curriculum can be achieved.

With the change, it seems that education in this country is not yet fully capable of giving birth to a generation of people who are not only intellectually intelligent but also emotionally, spiritually, and socially intelligent even those who change the curriculum often seem to be poorly prepared so that there is chaos or many weaknesses found in the field.

In an effort to achieve educational goals, the role of curriculum in formal education in schools is very strategic. Even the curriculum has a very central position and position in the whole process of education, and the curriculum is an absolute requirement and an integral part of education itself, because the role of curriculum is very important, it becomes the responsibility of all parties involved in the education process (Arifin, 2011: 13).

Regarding curriculum changes, it certainly has implications for changes in curriculum content/structure standards, process standards, and assessment standards in education. With this change, it requires the teacher to understand and implement all these changes in the learning process in the classroom, but not many teachers who understand and are able to implement these changes in learning activities, especially in the use of learning methods.

In addition to the teacher's understanding of each change that exists, the condition of students also greatly influences the success of educational goals. At the secondary or junior high school level, the condition of students is very unstable, so that teachers demand more professional competence in dealing with students. One part of teacher competency is pedagogic competence which includes the use of learning methods.

In accordance with the Minister of Education and Culture Regulation of 2014 concerning the structure of the curriculum in 2013 which contained the methods of learning Hinduism education and character, it contained six strategies in the concept of Hinduism called Sad Dharma, they are: dharma wacana, dharma tula, dharma santi, dharma yatra, dharma gitaand dharma sadhana. However, the implementation has not been fully implemented by Hindu teachers.

The existence of a curriculum change that has implications for the use of learning methods that have not been able to answer the objectives of Hinduism education as a whole indicates that there is still overlapping of these changes, meaning that there is no proper synergy between curriculum changes and the existence of the curriculum. Moreover, the existence of the Sad Dharma method certainly has an impact on the learning situation in the classroom and the 
quality of education in general. In applying the new method, of course, there are several constraints faced and have implications for students.

Starting from the aforementioned phenomena, the author was interested in studying more about the Sad Dharma method of learning Hinduism education and character, entitled "Sad Dharma as a Learning Method of Hindu Religious Education and Character of 2013 Curriculum in SMP GurukulaBangli" which was divided into 3 sub-topics namely, the firstwasthe implementation of the Sad Dharmamethod, the second was constraints faced in the implementationof the Sad Dharmamethod, and the third was implications of the implementationof the Sad Dharmamethod.

\section{Methods}

The type of research used was descriptive research with a qualitative approach. This research took place at SMPGurukulaBangli. The reasons for choosing the location in SMPGurukulaBangli are: (1) SMP Gurukula Bangli is one of the SMP that have Hindu nuances, (2) SMP Gurukula Bangli is one of the SMP using 2 curricula namely National curriculum (2013) and pasraman curriculum, (3) SMP Gurukula Bangli emphasizes character education, love and uses environment-based learning, and (4) SMP Gurukula Bangli students come from underprivileged children from all over Indonesia who are Hindus.

The type of data used in this study was qualitative data. The rationale for using qualitative data was in accordance with the type of research conducted, besides, it was used to examine a problem with a naturalistic setting. It used primary data sources obtained directly from informants through interview techniques. While the secondary data of this study were various reading resources such as books, journals, and research result whose contents were relevant to the topic of research. It used interview guidelines as an instrument of research and informant determination using a purposive sampling technique by selecting people who were seen to understand about the topics studied such as teachers, students, principals, supervisors and parents of students. In this study the data collection techniques used were: observation, interviews, literature study, and documentation. While data analysis used data reduction, data display, and conclusion drawing/verification.

\section{Results and Discussion}

3.1 The Implementation of Sad Dharma Method to Hinduism and Character Education Learning

Indeed, in the teachings of Hinduism, there are many teachings that can be used as a method of learning Hinduism education and character as an effort to inculcate the teachings of Hindu values. The method of fostering Hindus, and the method of religious education is a method and steps taken to instill the teachings of Hinduism into the hearts of students in general, so that religious teachings are truly an integral part in private students and Hindus. Efforts to implement these things are certainly through Sad Dharma, namely: (1) dharma wacana, (2) dharma tula, (3) dharma santi, (4) dharma gita, (5) dharma yatra and (6) dharma sadhana.

Interestingly the implementation of Sad Dharma method has coherence and relevance to modern learning methods. This indicates that there are many concepts in Hinduism that can be reduced and formulated into learning methods and approaches that are aligned with the implementation of modern learning methods. As Sad Dharma method which is applied to learning Hinduism education and manners at SMP Gurukula Bangli. The implementation can be described as follows.

\subsubsection{Dharma Wacana}

Dharma Wacana is the implementation of teaching with oral and written lectures reinforced using visual media. In this case, the role of the teacher as a source of knowledge is very dominant. Wirawan (2007: 1) explains that Dharma 
Wacana consists of two words, namely dharma and wacana. Dharma means obligation or swadharma to carry out the truth, and wacana is interpreted as a conceptual statement. Watra (2008: 2) explains the same thing, that dharma wacana is a method of illuminating Hinduism that is conveyed at every opportunity of Hindus who are associated with religious activities. Based on this matter, the dharma wacana method is the dominant method used to convey the teachings of Hinduism, including in learning activities at the SMP Gurukula Bangli.

Wirawan (2007: 3) explains that the dharma wacana method from the past has been carried out by the great teacher in Upanishad. The term Upanishad itself can be interpreted as sitting near the teacher to listen to the teachings of the sacred or spiritual knowledge. In the context of its use, discourse means a set of statements that can be grouped in certain conceptual categories. The definition emphasizes efforts to identify certain structures in the wacana which consists of several statements. With this matter, dharma wacana method, the teacher strives to provide detailed explanations, which are related to the material presented.

The method of dharma wacana has similarities with the lecture method. Because Rusman (2011: 90) explains that, the lecture method is a way of teaching by explaining the subject matter to students. The goal is that students can master the subject matter delivered by the educator. So, based on this thing, there are similarities between the dharma wacana method and the lecture method. The most important implementationof the dharma wacana method and the thing that must be clear is that the source which is the reference must be from the Hindu or Vedic scriptures. After that, further sources can be taken from the source of the Vedic translation. Learning religion with the dharma wacana method can obtain religious knowledge by listening to the teacher's advice. Dharma wacana methods are included in the realm of knowledge in the dimensions of Core Competence 3.

Dharma wacana method can be applied well. If a teacher can apply the dharma wacana method well, then it is not impossible that it can change the attitude and mentality of students. As has happened at the SMP Gurukula Bangli, where the implementation of the dharma wacana method has brought changes in attitudes and metal of the students, it has become better.

\subsubsection{Dharma Tula Method}

Dharma Tula is the implementation of teaching by holding discussions in the classroom. The word tula comes from Sanskrit which means consideration, likeness, and weighing. Traditionally, dharma tula was carried out in relation to dharma gita. Usually to get a clearer understanding of dharma gita which contains philosophical teachings. So, in this case, the dharma tula method is a learning method that emphasizes participation from two directions, namely between teacher and student.

The dharmatula method is used because each student has different intelligence. By using the dharmatula method, students can contribute to learning. Dharma tula in general means weighing on the mind, discussing religious studies to gain enlightenment and deepening of Hinduism. Maswinara (2009: 75) explains that in nyayadarsana, the method of debating or discussing is called tarkavada. This method is usually used in debating and refuting a topic of a problem, so finding the final answer to a problem. So, the dharma tula method with tarkavada has the same meaning, which refers to a method of discussion. In modern learning methods, the Dharma Tula method contains the same meaning as the method of discussion. Rusman (2011: 97) explains that the method of discussion is a method with steps or ways of expressing opinions. The goal, in order to achieve unity of opinion among students. Usually, all participants actively play a role 
and give reasons or discuss what is the subject of the conversation.

Dharma tula is often equated with the meaning of literature. The things discussed in dharma tula are the problem of tattwa, morality and sometimes also the problems that arise in the community that is felt to be incompatible with the implementationof the teachings of Hinduism. This is done to train sensitivity to the circumstances surrounding the community environment. Sensitivity to all events that occur around the environment is indeed necessary to instill in students early on. In addition, the implementationof the Dharma Tula method can later foster a critical attitude from the students, especially in responding to various phenomena in the community related to Hinduism. It is necessary to cultivate a critical attitude in each student, to foster sensitivity so that not only accept, but also need to be able to filter.

Based on the implementation of the Dharma Tula method at the SMPGurukulaBangli, it has a significant contribution to the growing critical attitude of the students, so that the knowledge gained by students is more profound. In the description above also explained, that there are several things that must be considered in carrying out teaching through the dharma tula method. For the teachers of the SMP Gurukula Bangli the three things in question have been applied optimally. In instilling the teachings of Hinduism through the dharma tula method, the teacher always delivered material based on Wada Literature. Likewise, when students ask, they are very concerned about aspects of culture, so that the discussion shows the atmosphere of the premawada.

\subsubsection{Dharma Santi Method}

The Dharma Santi method is the implementation of learning to instill mutual nurturing, mutual compassion and care that is full of tolerance. The dharma shanti method in learning provides an opportunity for students to recognize each other's classmates, so as to foster a sense of mutual love.

Dharma Santi methods will be taught to make peace with themselves and others. In addition, through this step, the teachings of love (premaswarupa) will be applied. In this regard, the teacher/educator applies the dharma santhi method at SMP Gurukula Bangli emphasizing behavior to love others, teachers, and all beings. Dharma Santi method is very relevant if it is used as steps to instill the teachings of Hinduism, especially the teachings relating to love. Religion is basically loved itself.

\subsubsection{Dharmagītā Method}

The Dharmagità method is the implementation of teaching with the pattern of chanting sloka, palawakya, and tembang. Teachers in the learning process with dharmagita patterns, involve the sense of art that each student has, especially sound or singing so that he can refine his mind. Dharmagita as a medium for delivering and deepening religious beliefs is very effective. Therefore, the delivery of Hindu teachings is woven in a beautiful and charming form of song or rhythm, enchanting readers and listeners. The effort to preserve and develop Dharmagìtā aims to maintain and preserve the traditional cultural heritage that is ignored by religion. In addition, through Dharmagit $\bar{a}$, it is hoped that it will be able to provide a touch of chastity, reverence, and fervor in carrying out religious activities.

Dharmagìta or kirtanam is one way to awaken the divine power within. Dharmagīta is a song about dharma. Dharma means the teachings of Hinduism which are packaged in the form of rites of spiritual singing so that those who sing and listen together can live and deepen their teachings. Then the delivery of dharmagit $\bar{a}$ material combines theory and practice. So that the implementationof this learning method at the SMPGurukulaBangli immediately practiced after the teacher explained and gave an example of one of the songs or sloka. 
From several quotes from the Vedas, about the importance of songs that contain the message of beauty as a religious media, Dharmagìta becomes very important in instilling the teachings of Hinduism, especially for students, as the younger generation who do not know much about the teachings of Hinduism. Based on the Vedic mantra, in this case, the teacher can instill the teachings of Hinduism to students with the method of the holy song (Dharmagit $\bar{a}$ ). The implementationof the Dharmagit $\bar{a}$ method in learning can also minimize learning that is "boring" for students because the Dharmagìtā method will make the learning process more interesting and varied.

\subsubsection{Dharma Sadhana Method}

DharmaSadhana is

is the

implementation of learning to foster social sensitivity of students through sincere giving or help and developing an attitude of sharing with others. DharmaSadana can literally be interpreted as the realization of the teachings of dharma in a person. Adnyana (2011: 35) explains that Dharma Sadana is an implementation of the teachings of sanathanadharma which is practiced through spiritual discipline or sadhana.

The method of sadhana is a method to foster a sense of spiritual discipline among the students. So that in this case, creating religious graduates can be implemented. The method of sadhana is basically oriented to the disciplines of personal life such as tapa, bratha, yoga, and Samadhi. For this reason, it is necessary to form a guideline in such a way that is practical and can be carried out by each congregation according to the age level of the student himself.

\subsubsection{Dharma Yatra Method}

Dharma yatra is the implementation of learning by visiting holy places. Dharma yatrastrategy is used both when explaining the material of the holy place, holy day, culture, and history of the development of Hinduism. Dharma yatra has an understanding that is almost the same as tirta yatra. Dharma yatra or tirta yatra as a sacred journey according to the book of Sarasamuscaya is said to be more important than faith. As stated in the following verse:

Apanmangkekottamaningtirthayatra, atyantapawitra,

lwihsakengkapawananingyajña, wenangulahkena ring daridra.

(Sarasamuccaya279)

Translation:

Because the virtue of tirtha yatra is very holy, more important than purification with yajña; because tirtha yatra can be done by even poor people (Kajeng, 2010: 212).

The virtues of the DharmaYatra can be done by even the poorest people. It is mentioned because the capital of Dharma Yatrais only a pure and sincere intention. To increase personal purity and faith in God Almighty, to see or expand the horizon to see the majesty of God, admire the universe and God's creation, so that it is more determined to practice the teachings of dharma. DharmaYatra is very well done for religious holy days or worship ceremonies at temples or holy places.

Associated with the DharmaYatra method on learning education in Hinduism and character at the SMPGurukulaBangli were well implemented. The DharmaYatra method is very appropriate to be used to encourage children to learn from the saturation of learning in class. Besides, students can pay attention directly to the object in question so that they will be easier to understand the subject matter.

3.2 Constraints Faced in the Implementation of the SadDharma Method to the Learning of Hindu Religious Education and Character 3.2.1 Internal Constraints

The implementation of the SadDharma method in learning the education of Hinduism and BudhiPakerti at SMPGurukulaBangli is inseparable from the obstacles faced. The most prominent obstacle is the obstacle that comes from 
internal students as objects and subjects of students. Internal constraints are often a limiting factor in the implementationof SadDharma learning methods. This has an impact on the learning process being hampered and not in accordance with the learning outcomes in the curriculum. Internal constraints in the implementationof SadDharma learning methods at the SMPGurukulaBangli consist of several factors, namely: physiology, fatigue in students and psychology.

Empirically there are students in SMPGurukulaBangliwho experience physical disorders (physiology). This becomes an obstacle for students. Because physical disability can be expressed as a delay in the development of students. The implementationof the Sad Dharma method in learning Hinduism education and manners at the SMPGurukulaBangliexperienced obstacles due to one student experiencing physical limitations (physical disability).

The second factor is physical fatigue can be in the form of physical learners, this is because students prepare all their own life needs in the garden, ranging from food, clothing and other necessities needed in the learning process. The uncomfortable atmosphere of the classroom can influence motivation and enthusiasm. and learning of students. Factors of fatigue from the physical and spiritual, must be avoided from students, because it will have an impact on the learning process of students in attending school lessons. Especially fatigue occurs in the lesson hours that have already stepped on the afternoon or in the last hours of the lesson.

The third factor is psychology, in developmental psychology seeing students as individuals as students in educational institutions, and trying to understand developments from a perspective throughout the human life span (Life-Span Development). The ultimate goal from this perspective is to help the lives of individuals become meaningful and productive lives. Starting from the description, there is clearly a strong correlation between the psychological development of students and the learning conditions and environment as well as the SMPGurukulaBanglistudents, if viewed from an individual perspective.

Students are seen personally (individually) as human beings with all their potential. Psychological education sees students as human beings and individual beings is a set of behaviors that are owned by humans and influenced by customs, attitudes, values, ethics, power, persuasion, and genetics. In the psychology literature in general, these scholars argue that the main determinants of human behavior and personality traits are physical states, psychological qualities, and environmental situations. These psychological factors become constrained themselves in the implementationof Sad Dharma learning methods. Because students are veryinfluenced by the environment in which they live, namely pasraman.

\subsubsection{External Constraints}

External constraints also cannot be ignored, because they are a limiting factor in the implementationof the Sad Dharma method of learning Hinduism education and character. External constraints are definitely related to things that are external to students as students in the learning process. External constraints can arise from human resources in this context, of course, referring to the human resources of teachers as human educators. The external constraints that hinder the implementationof the Sad Dharma method in learning Hinduism and character in SMP Gurukula Bangli are human resources, facilities, and infrastructure as well as the curriculum.

Factors of human resources have a very strong influence on the learning process. Hasbullah (2013: 124) explains that the teacher as an educator function as a guide, influence, to foster the activities of students and at the same time as the holder of responsibility for the implementation of education. Rusman (2011) explained that educators as facilitators in the learning process. Dantes (2008) also states that 
educators are those who have a duty as educators so that all potential within students will emerge.

Referring to the description, it clearly shows that the human resources of Hinduism teachers in SMPGurukulaBangli needs to be improved. Especially their mastery in learning strategies and approaches. The Sad Dharma method is actually a way of learning Hinduism and very relevant manners are used to increase the potential of intelligence both spiritual and physical students. The teacher's inability as an education in applying the Sad Dharma method certainly becomes a significant obstacle in the learning process.

Based on this, the teacher is required to be able to innovate, be creative and smart in developing learning based on sad dharma. The six methods are very compatible with modern learning methods, so teachers should be able to formulate sad dharma learning methods with modern ones. The goal is clear as mandated by the four pillars of WHO, that learning to know,learning to do, learning to be, and learning to live together (Dantes, 2008: 8).

The facilities and infrastructure factors are classified as educational tools. Educational equipment is one component that is very important in the learning process. Educational tools like Hasbullah (2013: 124) explain that everything that can be used to achieve educational goals that serve to facilitate or accelerate the achievement of educational goals. Based on these theoretical terms, educational tools can be expressed as a learning media used by teachers in the learning process. In this context, tools are not only in the realm of "media", but also include curriculum, methods, strategies and learning approaches. All educational components or tools each have a significant role in seeking learning to be effective and efficient. Being a failure of the world of education, if each of these educational tools does not work in a balanced manner. Because each of these tools is an inseparable entity. Each has a very strong connection, and cannot stand alone.

Curriculum factors have a very important role in the education system. The curriculum is present as the origin point in the implementation of education so that in the process of curriculum learning is always used as an educational base in trying to achieve learning goals (education). The implementation of the Sad Dharmamethod as a learning method also coherent with the curriculum as a learning device. Even the method can be integrated into the curriculum. Moreover, the 2013 curriculum with its integrated thematic approach. However, the disadvantage is that not all Hindu religious education teachers at SMPGurukulaBangliunderstand the 2013 curriculum.

\subsection{Implications of the Sad Dharma Method to the Learning of Hindu Religious Education and Character}

The implementation of the Sad Dharma method to the learning of Hinduism education and character certainly raises various implications. The implications of applying the Sad Dharma method that emerges are implications for spiritual attitudes, implications for social attitudes, implications for cognitive/knowledge, and implications for psychomotor/skills.

Implications for spiritual attitudes for students in SMP Gurukula Bangli are seen in students' behavior, both in learning and everyday life. Both male and femalein SMP Gurukula Bangl ihave strong spiritual attitudes. This indicates that the potential spirit in themselves has been well built through the learning process.

The religious life of students at the SMP Gurukula Bangli cannot separate them selves from learning activities and yadnya rituals. Students in SMPGurukulaBangliare always doing ceremonies, both in a small and large scale which are followed personally and communally. The ceremony shows a reflection of the value of education of religious characters who rely on the value of local wisdom and Hinduism as their spirit. This value is manifested in the behavior of students as students reflecting the Hindu spirituality. 
Implications for children's social attitudes appear in the creation of good social attitudes. Because students see that pasraman people are their family. Then the students live together in a family bond. Although genealogically they come from different family backgrounds, together they are taught to have a high social attitude. The most obvious social attitude is the tradition of praying together, cleaning together, eating together, and studying together. Moreover, there are some activities that can foster social attitudes and social solidity, so they assume that they are a large family of pasraman so that they can create a comfortable and conducive family environment for learning. In addition, Hinduism teachers and other teachers always emphasize an attitude of mutual respect, respect and basing attitudes on mutual respect.

Cognitive implications. Students do not only realize the character in behavior but also in aspects of cognition in the sense of "character knowledge". The increase occurred significantly, and the improvement in question was a change towards a better than before so that PasramanGurukula could truly be an agent of change (school as an agent of change). Students who are in pasraman, from the beginning have been trained to do habituation, this is the advantage of PasramanGurukula, because students are given the motivation to carry out positive activities, especially in the learning process. So that students in SMP Gurukula Bangli in the direction of their knowledge are not contaminated by bad influences. In the implications of students' knowledge more to their students concentrating on learning, because one of the basic objectives of applying the Sad Dharma method in learning Hinduism and character is to provide a sense of comfort in the form of a peaceful feeling that is able to give concentration to students. students who are members of the PasramanGurukula are provided with religious knowledge and direct guidance from the Hindu teacher so that the knowledge gained is very diverse and this is what distinguishes the pattern of pasraman education with formal schooling. With the development of religious values automatically spiritual adolescents will grow so that adolescents are able to distinguish which ones are good and which are bad for themselves.

Psychomotor/skills implications. Improving the character quality of psychomotor students in the learning process can be seen from the skills of students, they are skilled in nurturing the environment, skilled in cultural arts to sports. In Pasraman activities students are educated to be independent. The skills given by teachers to Gurukula Middle School students can be applied in daily life by students, such as in terms of sewing skills for female students in Pasraman. At least with mastery of sewing skills such as making canang or daksina can help pasraman when there are piodalan and holy days. In addition, students are very proud because they are at least able to show good behavior and have skills so that they can strengthen their sradha and devotion.

\section{Conclusion}

1. The implementationof the Sad Dharma method to the learning of Hinduism and manners in the SMP Gurukula Bangli includes several things, namely: (1) Dharma Wacana on the implementation of teaching with oral and written lectures reinforced using visual media. (2) Dharma Tula is the implementation of teaching by holding discussions in the classroom. (3) Dharma Shanti is the implementation of learning to instill an attitude of love. (4) Dharma Gita is the implementation of teaching with the pattern of chanting sloka, palawakya, and tembang. (5) Dharma Sadhana is the implementation of learning to foster the social sensitivity of students. (6) Dharma Yatra is the implementation of learning by visiting holy places.

2. Constraints faced in the implementationof Sad Dharma learning methods in the learning of Hindu religious education and the character of the SMPGurukulaBangli, namely: (1) Internal constraints caused by 
physiological and student fatigue factors. (2) External constraints caused by teacher factors, facilities, and curriculum.

3. Sad Dharma learning methods on learning Hinduism education and manners at the SMP Gurukula Bangli psychomotor/skills.

\section{References}

Adnyana I GedeAgus Budi.2011. Pala Sloka Pala Sruti Berkah Membaca Sloka Veda. Denpasar: Pustaka Bali Post.

Arifin, Zainal. 2011. Konsep dan Model Pengembangan Kurikulum. Bandung : PT Remaja Rosdakarya.

Dantes, I Nyoman. 2008. Pembelajaran Teknohumanistik (Jurnal Ilmiah UNDIKSA). Singaraja: Universitas Pendidikan Ganesha.

Hasbullah. 2013. Dasar-Dasar Ilmu Pendidikan. Jakarta: PT Raja Grafindo Perkasa.

Kajeng, I Nyoman. 2010. Sarasamusccaya. Surabaya: Paramita.

Maswinara, I Wayan. 2009. Filsafat Hindu Sarva Darsana Samgraha. Surabaya: Paramita.

Peraturan Menteri Agama Nomor 56 Tahun 2014. Tentang Pendidikan Agama dan Keagamaan Hindu.

Rusman. 2011. Model-Meodel Pembelajaran, Jakarta : PT Rajindo Persada
Undang-Undang Republik Indonesia Nomor 20 Tahun 2003 tentang Sistem Pendidikan Nasional. 2010. Yogyakarta: Bening.

Watra, I Wayan. 2008. Pengantar Filsafat Pendidikan Agama Hindu. Denpasar: UNHI Denpasar Program Pascasarjana.

Wirawan, Ida Bagus Ketut.2007. Beragam Metode Siar Hindu Teori dan Teknik serta Aplikasi. Surabaya: Paramita. 